\author{
WIOLETTA JUNIK \\ Uniwersytet Kazimierza Wielkiego \\ $w$ Bydgoszczy
}

\title{
WYBRANE NARZĘDZIA DO POMIARU REZYLIENCJI (RESILIENCE) WŚRÓD DZIECI I MŁODZIEŻY
}

\begin{abstract}
Junik Wioletta, Wybrane narzędzia do pomiaru rezyliencji (resilience) wśród dzieci i młodzieży [Selected Tools for Measuring Resilience Among Children and Adolescents from Risk Groups]. Studia Edukacyjne nr 41, 2016, Poznań 2016, pp. 335-357. Adam Mickiewicz University Press. ISSN 1233-6688. DOI: $10.14746 /$ se.2016.41.21
\end{abstract}

The interest in research in resilience among children and adolescents from risk groups is rising. Resilience is a multifactorial process of positive adaptation during which risk factors are reduced or compensated by protective factors. The measure of resilience requires research tools which satisfy certain psychometric standards. Many tools which satisfy these requirements already exist in the world; some are already used in many different cultures. There is a deficiency of resilience measuring instruments in our country. No local ones have been created and not many foreign have been adapted in Poland. That is the reason this article presents characteristics and psychometric properties of a few selected scales used to measure resilience and resiliency of children and adolescents. The selection of the tools has been done with use of Google Scholar Database, EBSCO Database and on the grounds of analysis of foreign resilience tool reviews.

Key words: resilience, measure, children and youth, review

\section{Wprowadzenie}

Emmy E. Werner 60 lat temu zainicjowała na hawajskiej wyspie Kauai badania longitudinalne nad rozwojem 698 azjatyckich i polinezyjskich dzieci. Dane o nich zbierała od chwili ich narodzin do 40. roku życia. Pomiary prowadzone w dzieciństwie dowiodły, że wśród około 200 dzieci zaliczonych do grup ryzyka z powodu różnego rodzaju zagrożeń rozwojowych, 
u 72 nie zaobserwowano żadnej psychopatologii ${ }^{1}$. Odkrycie to zapoczątkowało nowy nurt badań, skoncentrowany na poszukiwaniu różnic indywidualnych pomiędzy ludźmi (zwłaszcza u dzieci i młodzieży) sprzyjających występowaniu tego zjawiska, które nazwano resilience (z języka angielskiego) ${ }^{2}$, a także na odkrywaniu uwarunkowań radzenia sobie $z$ przeciwnościami, co przyczyniło się do pojawienia koncepcji wyjaśniającej odkryty przez E.E. Werner fenomen.

W Polsce zainteresowanie zjawiskiem i koncepcją rezyliencji3 (wyjaśniającą jego mechanizmy) pojawiło się na początku nowego tysiąclecia. Pierwsze kilka lat to był czas upowszechniania wiedzy o samym zjawisku i jego uwarunkowaniach przez niewielu badaczy ${ }^{4}$. Natomiast bezprecedensowe badania podłużne na kilkutysięcznych populacjach polskiej młodzieży, których podstawą teoretyczną była między innymi koncepcja rezyliencji, zostały przeprowadzone $\mathrm{w}$ latach 2006-2008 przez zespół badaczy z Pracowni Profilaktyki Młodzieżowej „Pro-M” Instytutu Psychiatrii i Neurologii w Warszawie, pod kierunkiem Krzysztofa Ostaszewskiego ${ }^{5}$. W tym samym czasie zespół z Instytutu Matki i Dziecka w Warszawie, pod kierunkiem Joanny Mazur, prowadził badania nad uwarunkowaniami zjawiska rezy-

${ }^{1}$ E.E. Werner, Children of the Garden Island, Scientific American, 1989, 260, 4, s. 76-81.

2 Resilience to termin zaczerpnięty z fizyki, który nawiązuje do właściwości odzyskiwania pierwotnej formy przez materiały fizyczne po przejściu pewnej deformacji wynikającej z nacisku bądź do procesu powrotu do dawnej formy po odkształceniu (zob. F. Vitaro, R. Carbonne$\mathrm{au}, \mathrm{J} . \mathrm{M}$. Assaad, Les enfants de parents affectés d'une dépendence. Problemes et resilience, Québec 2006, s. 85). Stąd, z jednej strony resilience może oznaczać właściwość jednostki, a z drugiej pewien proces, $\mathrm{w}$ którym ona uczestniczy. Zabieg zapożyczenia wynikał z faktu, że w naukach o człowieku brakowało terminu, który w pełni oddawałby istotę zjawiska.

${ }^{3}$ Autorka artykułu używa spolszczonej nazwy dla zjawiska resilience, ponieważ w języku polskim także brakuje jednoznacznego terminu. Ponadto, uważa, że zabieg spolszczenia może sprzyjać upowszechnianiu wiedzy o tym zjawisku, ułatwiając jego wymowę np. osobom nieznającym języka angielskiego, tym samym zwiększając zainteresowanie zjawiskiem w praktyce edukacyjnej. Obszerne rozważania na temat etymologii pojęcia resilience i interpretowania jego znaczenia znajdują się m.in. w pracy: W. Junik, Zjawisko rezyliencji - wybrane problemy metodologiczne, [w:] Resilience. Teoria - badania - praktyka, red. W. Junik, Warszawa 2011, s. 47-65.

${ }^{4}$ Pionierskie prace na tym polu publikował zespół badaczy z Pracowni Profilaktyki Młodzieżowej „Pro-M” z Instytutu Psychiatrii i Neurologii w Warszawie, pod kierunkiem Krzysztofa Ostaszewskiego.

${ }^{5}$ K. Ostaszewski, A. Rustecka-Krawczyk, M. Wójcik, Czynniki chroniące i czynniki ryzyka związane z zachowaniami problemowymi warszawskich gimnazjalistów. Raport $\mathrm{z}$ realizacji I etapu badań: „Rola czynników ryzyka i czynników chroniących w rozwoju zachowań problemowych u młodzieży szkolnej. Badania warszawskich gimnazjalistów", Warszawa 2008; K. Ostaszewski, Badania warszawskich gimnazjalistów. Koncepcja i metoda, [w:] Promocja zdrowia psychicznego: badania $i$ dziatania w Polsce. Część druga, red. K. Okulicz-Kozaryn, K. Ostaszewski, Warszawa 2010, s. 123-144. 
liencji w kontekście samopoczucia młodzieży ${ }^{6}$. Unikalny charakter obydwu tych badań polega na tym, że są to pierwsze i nadal jedyne próby weryfikacji skomplikowanych modeli wyjaśniających mechanizmy chroniące polską młodzież przed podejmowaniem zachowań ryzykownych i problemowych.

Inne pionierskie badania przeprowadziła Iwona Grzegorzewska7, dostarczając wiedzy o procesie rezyliencji $\mathrm{w}$ rozwoju dzieci $\mathrm{z}$ rodzin alkoholowych. Ich celem było ustalenie momentu pojawienia się u tych dzieci zachowań wskazujących na pozytywną adaptację i zidentyfikowanie czynników ryzyka oraz czynników chroniących determinujących występowanie rezyliencji na różnych etapach ich życia.

Większość badań nad zjawiskiem rezyliencji w Polsce przeprowadzono na osobach dorosłych ${ }^{8}$. O rezyliencji u dzieci nadal wiadomo niewiele.

Jedną z przyczyn tego stanu rzeczy może być fakt, że w Polsce bardzo rzadko konstruuje się lub adaptuje narzędzia stosowane $\mathrm{w}$ innych krajach do pomiaru zjawiska rezyliencji dzieci i młodzieży ${ }^{9}$. Potwierdza to monitoring stanu wiedzy naukowej na ten temat prowadzony systematycznie przez autorkę artykułu. Brakuje także artykułów przeglądowych dotyczących narzędzi badawczych spełniających wysokie standardy metodologiczne, które zachęcałyby do wzrostu zainteresowania nimi. Próbę wypełnienia tej luki podjęli Nina Ogińska-Bulik i Zygfryd Juczyński ${ }^{10}$.

Celem niniejszego artykułu jest prezentacja informacji o wybranych, często wykorzystywanych na świecie narzędziach badawczych do pomiaru zjawiska rezyliencji wśród dzieci i młodzieży ${ }^{11}$ godnych polecenia badaczom. Zostaną w nim przedstawione sposoby definiowania zjawiska rezy-

${ }^{6}$ J. Mazur, I. Tabak, Koncepcja resilience od teorii do badań empirycznych, [w:] Czynniki chroniace młodzież 15-letnia przed podejmowaniem zachowań ryzykownych, Raport z badań HBSC 2006, red. J. Mazur, I. Tabak, A. Małkowska-Szkutnik, K. Ostaszewski, H. Kołoło, A. Dzielska, A. Kowalewska, Warszawa 2008, s. 599-605.

${ }^{7}$ I. Grzegorzewska, Odporność psychiczna dzieci alkoholików, Warszawa 2013.

${ }^{8}$ Dane zbierano za pomocą narzędzi rodzimych i zaadaptowanych. Badania te prowadzono na gruncie takich nauk i dyscyplin, jak: psychologia, psychopatologia, medycyna, psychiatria, w różnych ośrodkach naukowych. Prowadzili je: Nina Ogińska-Bulik, Zygfryd Juczyński, Aleksandra Kühn-Dymecka, Helena Sęk, Łukasz Kaczmarek i inni.

${ }_{9}$ Do grona badaczy, którzy podjęli taką aktywność należą: N. Ogińska-Bulik, Z. Juczyński, Ł. Kaczmarek.

${ }^{10}$ N. Ogińska-Bulik, Z. Juczyński, Skala Pomiaru Prężności (SPP-25), Nowiny Psychologiczne, 2008, 3, s. 39-56; tychże, Osobowość. Stres a zdrowie, Warszawa 2008; tychże, Prężność u dzieci i młodzieży: charakterystyka i pomiar - Polska skala SPP-18, Polskie Forum Psychologiczne, 2011, 16,1 , s. 7-28.

11 Autorka przeglądu wyraża nadzieję, że jego wartością dodaną będzie wskazanie czytelnikowi aktualnych, polskich i zagranicznych, źródeł naukowych, w których podejmuje się problematykę rezyliencji nie tylko w kontekście pomiaru tego zjawiska. 
liencji, zastosowana metoda poszukiwania danych o narzędziach badawczych do jego poznawania u dzieci i młodzieży oraz krótka charakterystyka tych, które autorka artykułu uznaje za godne zainteresowania.

\section{Zjawisko rezyliencji (resilience)}

Wraz z rozwojem badań nad zjawiskiem rezyliencji pojawiały się nowe ustalenia co do jego istoty. Zgromadzona wiedza na ten temat pozwala rozpatrywać ją w kategoriach: cechy osobniczej czy zestawu cech, jakiegoś końcowego efektu, czy też procesu' ${ }^{12}$.

Rezyliencja interpretowana $\mathrm{z}$ perspektywy indywidualnego zasobu jednostki oznacza na przykład jej zdolność do oderwania się (ang. bogunce-back) od negatywnych doświadczeń i elastycznego przystosowania do ciągle zmieniających się warunków ${ }^{13}$, za pomocą pozytywnych emocji14, czy też zdolność do bycia odpornym i do samonaprawy, stawania twarzą w twarz z przeciwnościami losu'15. Część badaczy tak interpretujących rezyliencję zaznacza ten fakt poprzez użycie terminu resiliency lub ego-resiliency. Niestety, wielu autorów tego nie czyni, co w rezultacie, biorąc pod uwagę podobieństwo leksykalne resilience i resiliency, wprowadza chaos terminologiczny do teorii i praktyki. W Polsce najczęściej resiliency tłumaczone jest jako: sprężystość psychiczna, prężność psychiczna bądź osobowa lub inaczej prężność ego, czy też odporność psychiczna ${ }^{16}$. Wielu badaczy słusznie podkreśla konieczność

12 Obszerne wyjaśnienia poświęcone istocie rezyliencji można znaleźć w: K. Nadolska, H. Sęk, Społeczny kontekst odkrywania zasobów odpornościowych, czyli czym jest resilience $i$ jak ono funkcjonuje, [w:] Bliżej serca, red. Ł. Kaczmarek, A. Słysz, Poznań 2007, s. 13-38; N. OgińskaBulik, Z. Juczyński, Skala Pomiaru Prężności (SPP-25), s. 39-56; K. Ostaszewski, Druga strona ryzyka, Remedium, 2005, 2(144), s. 1-3; tegoż, Badania warszawskich gimnazjalistów, s. 123-144; tegoż, Zachowania ryzykowne młodzieży w perspektywie mechanizmów resilience, Warszawa 2014; A. Borucka, Koncepcja resilience. Podstawowe założenia i nurty badań, [w:] Resilience. Teoria - Badania - Praktyka, s. 47-55; K. Szwajca, Sprężystość (resilience) i odpowiedzi na doświadczenia urazowe fascynujacy i trudny obszar badań, Psychiatria Polska, 2014, 48(3), s. 563-572.

13 J. Block, A.M. Kremen, IQ and ego-resiliency: Conceptual and empirical connections and separateness, Journal of Personality and Social Psychology, 1996, 70, s. 349-361.

14 M.M Tugde, B.L. Fredrickson, Resilient Individuals Use Positive Emotions to Bounce Back From Negative Emotional Experiences, Journal of Personality and Social Psychology, 2004, 86, 2, s. 320-333.

15 S.J. Wolin, S. Wolin, The Resilient Self: How Survivors of Troubled Families Rise Above Adversity, New York 1993.

16 Zob. Ł. Kaczmarek, H. Sęk, M. Ziarko, Sprężystość psychiczna i zmienne pośredniczace w jej wptywie na zdrowie, Przegląd Psychologiczny, 2011, 54, 1; N. Ogińska-Bulik, Z. Juczyński, Skala Pomiaru Prężności (SPP-25), s. 39-56; tychże, Osobowość. Stres a zdrowie; Z. Uchnast, Prężność osobowa: Empiryczna typologia i metoda pomiaru, Roczniki Filozoficzne, 1997, 4, s. 27-50; R. Opora, 
stosowania rozróżnienia pomiędzy tymi terminami, ponieważ odnoszą się one do różnych teorii i procesów psychologicznych. Z perspektywy koncepcji resiliency poszukuje się odpowiedzi na pytanie, jak zasób indywidualny, np. w postaci cechy osobowości, rzutuje na poziom funkcjonowania ludzi. Natomiast koncepcja resilience używana jest do wyjaśnienia uwarunkowań czynników sprzyjających pozytywnej adaptacji17 lub inaczej mówiąc - do zrozumienia mechanizmów zachodzących pomiędzy nimi. Część badaczy twierdzi również, że rezyliencji nie należy odnosić wyłącznie do właściwości osoby, ponieważ zgodnie z jej koncepcją ujawnia się ona $\mathrm{w}$ zachowaniu jednostki, ale nie jest jej cechą, co oznacza, że jednostka może posiadać jakieś odpornościowe wzory zachowań a nie, że jest odporna ${ }^{18}$.

Wyjaśnianie rezyliencji $\mathrm{w}$ kategorii efektu oznacza pozytywny rezultat rozwoju $\mathrm{w}$ niekorzystnych warunkach, opisywany przez pozytywne przystosowanie, radzenie sobie lub kompetencje. Stevenson Fergus i Marc A. Zimmerman nie zgadzają się $\mathrm{w}$ pełni $\mathrm{z}$ taką interpretacją. Ich zdaniem, jedynie proces przezwyciężania ryzyka jest rezyliencją, bo pozytywne przystosowanie może odnosić się również do młodych ludzi nie wystawionych na ryzyko. Jak twierdzą ci sami badacze, rezyliencja nie jest tożsama z kompetencją, którą należy traktować jako indywidualny poziom czynnika chroniącego, będącego istotnym elementem $\mathrm{w}$ procesie rezyliencji, procesie pokonywania przeciwności losu ${ }^{19}$. Innymi rezultatami rezyliencji mogą być także: unikanie negatywnych następstw lub poradzenie sobie z powodzeniem z traumatycznym zdarzeniem (np. śmierć ukochanej osoby).

Współcześnie rezyliencja definiowana jest najczęściej jako wieloczynnikowy proces pozytywnej adaptacji, $\mathrm{w}$ trakcie którego czynniki ryzyka są redukowane lub kompensowane przez czynniki chroniące. Przyczyniły się do tego wyniki wielu badań, dowodzące, że rezyliencja ma związek z interakcją pomiędzy rozległym spektrum trzech grup czynników: indywidualnych, rodzinnych i społecznych pozarodzinnych, zarówno ryzyka jak i chroniących ${ }^{20}$. Efekty tej interakcji mogą neutralizować negatywne działa-

Ewolucja niedostosowania społecznego jako rezultat zmian w zakresie odporności psychicznej i znieksztatceń poznawczych, Gdańsk 2009; I. Grzegorzewska, Odporność psychiczna dzieci alkoholików.

17 Zob. H. Sęk i in., Sprężystość psychiczna a dobrostan w chorobie przewlektej - mediująca rola podmiotowego umocnienia i radzenia sobie, Polskie Forum Psychologiczne, 2012, 17, s. 327-343.

18 A. Borucka, K. Ostaszewski, Koncepcja resilience. Kluczowe pojęcia i wybrane zagadnienia, Medycyna Wieku Rozwojowego, 2008, XII, 2, I, s. 587-597.

${ }_{19}$ S. Fergus, M.A. Zimmerman, Adolescent Resilience: A Framework for Understanding Healthy Development in the Face of Risk, Annual Reviews Public Health, 2005, 26, s. 399.

20 E. Valdenbilt-Adriance, D.S. Shaw, Conceptualizing and Re-Evaluating Resilience Across Levels of Risk, Time, and Domains of Competence, Clinical Child and Family Psychology Review, 2008 , s. 31. 
nie czynników ryzyka, zwiększać ogólną odporność jednostki, wyzwalać energię i procesy odwrotne do tych, które prowadzą do choroby, zaburzenia lub nieprzystosowania. $W$ tym rozumieniu istotą rezyliencji jest działanie czynników chroniących, które uruchamiają pewne określone mechanizmy ochronne przeciwstawiające się mechanizmom ryzyka ${ }^{21}$. Oznacza to, że o zjawisku rezyliencji możemy mówić tylko wówczas, kiedy spełnione są dwa warunki: jednostka jest narażona na znaczne zagrożenie lub poważne przeciwności losu i pomimo tego pozytywnie się adaptuje.

Reasumując, można powiedzieć, że rezyliencja definiowana w kategoriach interakcji pomiędzy czynnikami ryzyka i czynnikami chroniącymi występującymi $\mathrm{w}$ jednostce i jej środowisku staje się konstruktem ekologicznym i najczęściej w tym kontekście jest współcześnie wyjaśniana. Wynika to $\mathrm{z}$ założenia, że osoba narażona na ryzyko nie może jej rozwinąć za pomocą siły woli, ale poprzez interakcje ze środowiskiem, rodziną, szkołą, sąsiedztwem oraz szerszą społecznością22. Do zasobów wchodzących $\mathrm{w}$ interakcję $\mathrm{z}$ indywidualnymi czynnikami chroniącymi jednostkę (jak np.: zdolności poznawcze, temperament, mechanizmy samokontroli, optymizm i pogoda ducha, umiejętności społeczne, pozytywny obraz siebie, procesy motywacyjne) zalicza się czynniki wynikające z relacji z rodzicami oraz innymi znaczącymi osobami z najbliższego otoczenia (relacje rodzice-dziecko, konstruktywni rówieśnicy, dobrzy i kompetentni dorośli). Uwzględnia się także zasoby środowiska lokalnego (dobra szkoła, oferta angażowania się w konstruktywną działalność, przyjazne i bezpieczne sąsiedztwo) ${ }^{23}$.

Powyższe wyjaśnienia terminologiczne wyraźnie sugerują, że w pomiarze rezyliencji należy uwzględniać ocenę ryzyka i przeciwności losu, identyfikację zasobów, które mogą zrównoważyć wpływ ryzyka i same rezultaty rozwojowe. Takie badania wymagają tworzenia hipotetycznych modeli interakcji między tymi czynnikami ${ }^{24}$ i narzędzi o wysokich wartościach psychometrycznych.

${ }^{21} \mathrm{~K}$. Ostaszewski, Czynniki ryzyka i czynniki chroniace w zachowaniach ryzykownych dzieci i mtodzieży, [w:] Czynniki chroniace mtodzież 15-letnia, s. 32.

22 J.E. Brooks, Strengthening resilience in children and youths: Maximizing opportunities through the schools, Children and Schools, 2006, 28(2), s. 70; Risk to Resilience: Promoting School-Health Partnerships for Children, red. J.W. Richardson, International Journal of Educational Reform, 2008, 17, 1, Winter.

${ }^{23}$ K. Ostaszewski, Czynniki ryzyka i czynniki chroniące, s. 38-39.

${ }^{24}$ K. Ostaszewski, Druga strona ryzyka, s. 2. 


\section{Narzędzia badawcze do pomiaru rezyliencji}

Poszukiwania informacji o narzędziach badawczych odbyły się za pośrednictwem dwóch źródeł: Bazy danych EBSCO i wyszukiwarki internetowej Google Scholar. Poprzez EBSCO analizowano bazy danych zawierające prace $\mathrm{z}$ nauk społecznych, humanistycznych i medycznych, ponieważ w tych obszarach rozwijały się i rozwijają badania nad zjawiskiem rezyliencji. Przeanalizowano następujące bazy pełnotekstowe: Academic Search Complete, PsycARTICLES, ERIC, Health Source - Consumer Edition, Health Source: Nursing/Academic Edition, MEDLINE, Teacher Reference Center. Przede wszystkim poszukiwano opublikowanych w recenzowanych czasopismach naukowych artykułów przeglądowych dotyczących sposobów pomiaru rezyliencji z ich krytyczną analizą, a następnie źródeł uzupełniających te przeglądy. Przyjęto cezurę czasową od roku 2000 do 2015.

Do wyszukiwania publikacji za pośrednictwem bazy EBSCO wykorzystano słowa/zwroty kluczowe obecne $\mathrm{w}$ tytułach publikacji i ich abstraktach. Były to: "resilience-measure/measuring” (rezyliencja-pomiar/mierzyć), "resilience/resiliency scale" (rezyliencja/rezylientność - pomiar/mierzyć), w zestawieniu ze słowem "review" (przegląd). Wybór prac zawężono poprzez wskazanie populacji dzieci i młodzieży "child/ren", ",adolescent/s", "youth" (dziecko/dzieci, adolescent/adolescenci, młodzież) - potencjalnych respondentów. Znajdowanie artykułów poprzez wyszukiwarkę Google Scholar odbywało się na podstawie tych samych zwrotów kluczowych, jednakże ze wskazaniem psychologii jako dziedziny nauki, do której odnosić się miały prace. Zastosowanie różnych konfiguracji wymienionych słów kluczowych wyłoniło niewielką liczbę artykułów naukowych spełniających ogólne kryteria wyszukiwania i umożliwiło szybkie wyłonienie artykułów do analizy. Na przykład, wyszukiwanie za pośrednictwem baz danych zgromadzonych w EBSCO, będące połączeniem angielskich słów: rezyliencja, pomiar, dzieci, adolescenci, czy młodzież, umożliwiło wyłonienie 15 prac. Z kolei zestawienie: rezyliencja, przegląd, skala/e już tylko 5, z czego jedynie 4 to pełnotekstowe publikacje. Analogiczna sytuacja miała miejsce przy zastosowaniu Google Scholar. W tej przeglądarce 4 najwyżej pozycjonowane artykuły przeglądowe $\mathrm{z}$ omawianej tu problematyki znaleziono również poprzez EBSCO.

Warunkiem wyboru artykułu przeglądowego do zaprezentowania w niniejszej publikacji było przedstawienie przez jego autorów szczegółowych charakterystyk narzędzi uwzględniających opis teoretycznych podstaw narzędzia, jego konstrukcję, czy informacje o właściwościach psychometrycznych. Jedynie dwa zespoły autorskie precyzyjnie opisały metodologię zbie- 
rania danych o narzędziach, podając kryteria włączania i wyłączania prac do przeglądu ${ }^{25}$.

Opierając się na wyżej opisanych kryteriach, przeanalizowano 4 artykuły przeglądowe odnośnie narzędzi badawczych do pomiaru rezyliencji. Są to teksty autorstwa:

- Nancy Anhern, Ermalynn M. Kiehl, Mary Lou Sole, Jacqueline Byers²6 z 2006 roku;

- Gilla Windle'a, Kate M. Bennett, Jane Noyes ${ }^{27}$ z 2011 roku;

- Darlene Kordich Hall28 z 2010 roku;

- Belindy Basca $^{29}$ z 2002 roku.

W tabeli 1 zaprezentowano podstawowe dane i charakterystykę metodologiczną tylko dwóch przeglądów. Pozostałe (Kordich Hall i Basca) nie spełniały przyjętych przez autorkę tego artykułu kryteriów naukowych. Jednakże, w dalszej części artykułu znajdują się informacje z nich pochodzące, z uwagi na ich popularyzatorską wartość.

Jak obrazuje powyższa tabela, najobszerniejszym źródłem wiedzy o narzędziach do pomiaru rezyliencji wśród dzieci i młodzieży jest przegląd opracowany przez Windle'a i wsp. ${ }^{30}$ Lektura artykułu wskazuje na wysoki poziom naukowy analizy.

Autorzy bardzo szczegółowo przeanalizowali poszczególne narzędzia, używając do oceny ich jakości między innymi systemu punktowego. Precyzyjnie zdefiniowali wszystkie właściwości, które przyjęli za podstawę oceny jakości narzędzia. Do nich opracowali szczegółowe kryteria wraz ze wskaźnikami. Przegląd zawiera praktyczne zestawienie, w którym autorzy oprócz podstawowych danych o narzędziu przedstawili uwagi krytyczne do teoretycznych podstaw konstrukcji każdego narzędzia i doboru itemów. Na uwagę

${ }^{25}$ N.R. Ahern i in., A Review of Instruments Measuring Resilience, Issues in Comprehensive Pediatric Nursing, 2006, 29(2), s. 103-125; G. Windle, K.M. Bennett, J. Noyes, A methodological review of resilience measurement scales, Health and Quality of Life, 2011, 9, s. 8.

${ }^{26}$ N.R. Ahern i in., A Review of Instruments Measuring Resilience.

${ }^{27}$ G. Windle. K.M. Bennett, J. Noyes, A methodological review of resilience measurement scales, s. 8.

28 D. Kordich Hall, Compendium of Selected Resilience and Related Measures for Children and Youth. APPENDIX E: Annotated Compendium of Resilience Measures Reaching IN Reaching OUT, The Child \& Family Partner, Toronto 2010, http://www.reachinginreachingout. com/documents/APPENDIX\%20E $\% 20$ - $\% 20$ Annotated $\% 20$ Compendium $\% 20$ of $\% 20$ Resilience\%20Measures.pdf [dostęp: 18.02.2015].

29 B. Basca, Literature review of youth development/asset tools, The EMT Group, Inc. 2002, http://www.emt.org/userfiles/YouthLit_Final.pdf, [dostęp: 15.06.2015].

${ }^{30}$ G. Windle. K.M. Bennett, J. Noyes, A methodological review, s. 8. 


\begin{tabular}{|c|c|c|c|c|c|c|c|c|}
\hline \multirow{7}{*}{ 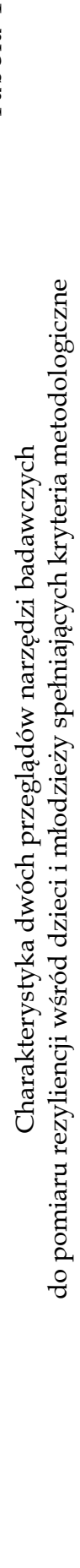 } & \multicolumn{8}{|c|}{ 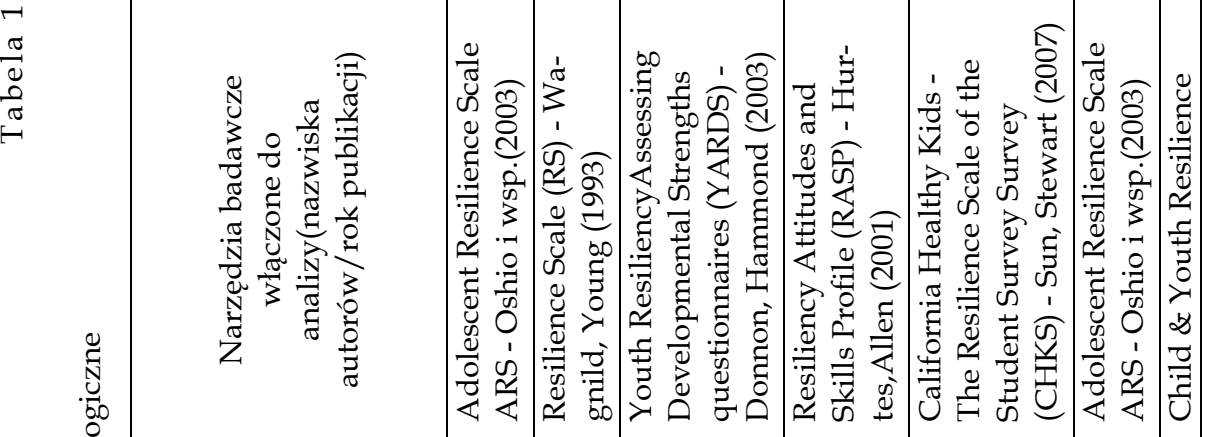 } \\
\hline & 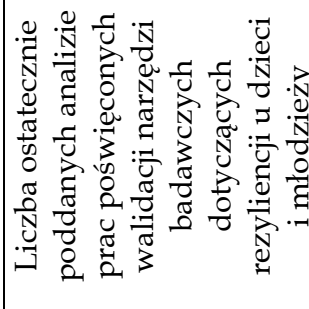 & & $N$ & & 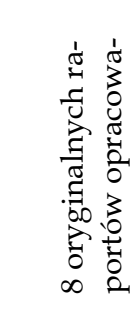 & 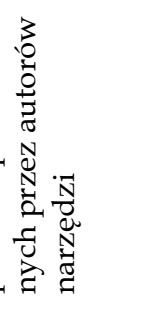 & & \\
\hline & 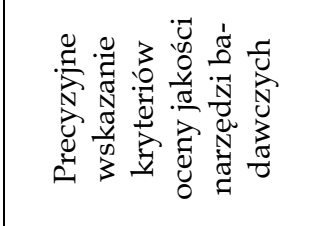 & & 光 & & 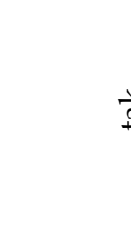 & 光 & & \\
\hline & 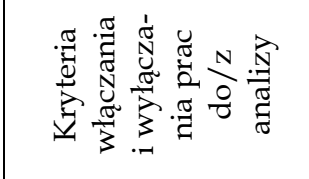 & & త్ & & 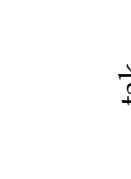 & $\frac{v}{\tau}$ & & \\
\hline & 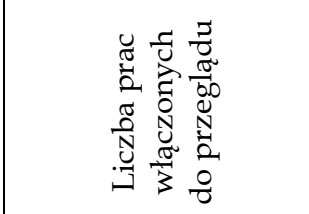 & & $\begin{array}{l}R \\
\text { }\end{array}$ & & 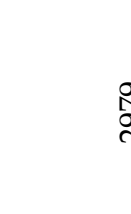 & ฟ & & \\
\hline & 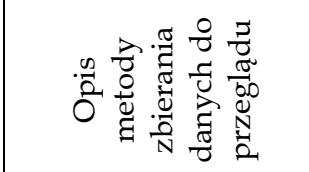 & & త్ & & & ๘ & & \\
\hline & 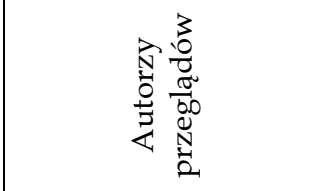 & & $\begin{array}{l}1 \\
\dot{2} \\
\text { का } \\
3 \\
.1\end{array}$ & & 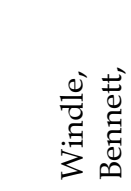 & $\begin{array}{l}1 \\
0 \\
2 \\
0 \\
2 \\
\text { Z }\end{array}$ & & \\
\hline
\end{tabular}




\begin{tabular}{|c|c|}
\hline 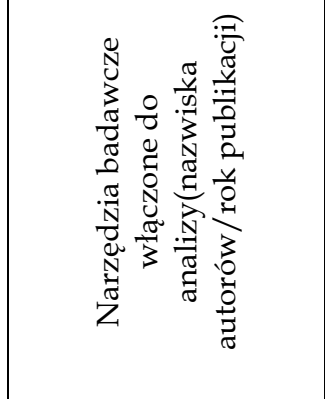 & 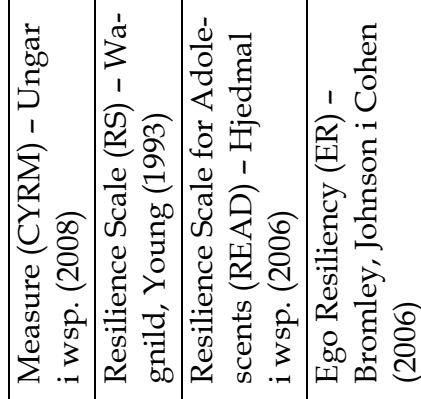 \\
\hline 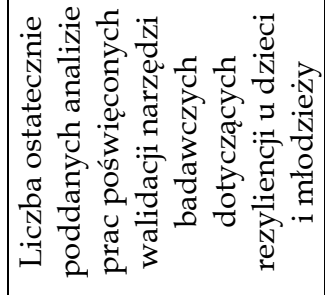 & \\
\hline 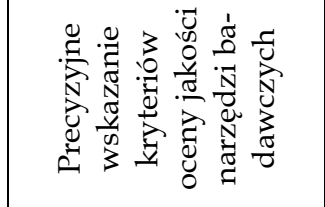 & \\
\hline 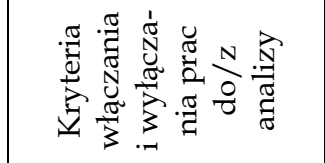 & \\
\hline 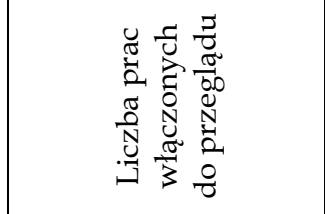 & \\
\hline 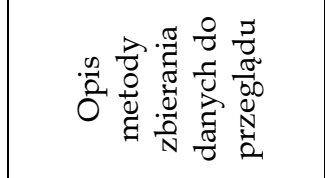 & \\
\hline 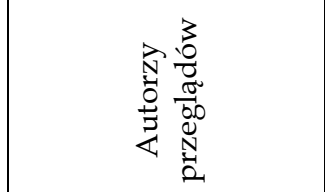 & \\
\hline
\end{tabular}


zasługuje sposób podsumowania procesu oceny narzędzi badawczych. Autorzy zastosowali skalę od 0 do 18 pkt. obejmującą wszystkie kryteria oceny. W tabeli zilustrowano rozkład liczby punktów uzyskanych przez narzędzia za spełnienie każdego z kryteriów jakości. Jak wynika z zestawienia, najwyższa łączna nota uzyskana przez narzędzie do pomiaru rezyliencji wyniosła zaledwie 7 pkt. i było to narzędzie dla dorosłych. Natomiast, spośród narzędzi dla młodzieży najlepszą notę uzyskała Resilience Scale (RS) - 6 pkt. Niestety, jedyne $w$ tym przeglądzie narzędzie do pomiaru rezyliencji u dzieci - California Healthy Kids - The Resilience Scale of the Student Survey (CHKS) uzyskało zaledwie 2 pkt.

Drugim rzetelnym źródłem wiedzy o narzędziach jest przegląd dokonany przez Ahern i wsp. ${ }^{31}$, ponieważ autorzy zadbali o przedstawienie metodologii zastosowanej do zbierania danych o narzędziach i sposobach oraz kryteriach ich analizy. Oprócz prezentacji istotnych podstawowych informacji na temat konstrukcji sześciu poddanych analizie narzędzi autorzy podali opis badań walidacyjnych, właściwości psychometryczne, wady i zalety, oraz źródła informacji o narzędziach. Na podstawie wybranych kryteriów oceny dokonali też podsumowania i ustalili ocenę końcową narzędzia. W tym przeglądzie, podobnie jak u G. Windle'a i wsp., najwyższą notę otrzymała skala RS Wagnilda i Younga.

Artykuł przeglądowy Kordich Hall ${ }^{32}$ zawiera charakterystykę aż 16 narzędzi do pomiaru rezyliencji, z czego 7 zostało szczegółowo przeanalizowanych również $w$ przeglądzie Windle'a i wsp. Oto pozostałe popularne narzędzia scharakteryzowane przez Kordich Hall:

- Devereux Early Childhood Assessment Program (DECA) 33;

- Devereux Student Strengths Assessment (DESSA/DESSA - mini) ${ }^{34}$;

- Resiliency Belif System Scale (RBS) 35 ;

- Resiliency Scales for Children and Adolescents (RSCA) 36 ;

31 N.R. Ahern i in., A Review of Instruments Measuring Resilience, s. 103-125.

32 D. Kordich Hall, Compendium of Selected Resilience.

33 P.A. LeBuffe, J.A. Naglieri, The Devereux Early Childhood Assessment (DECA): A Measure of Within-Child Protective Factors in Preschool Children, NHSA Dialog: A Research-to-Practice Journal for the Early Childhood Field, 1999, 3, 1, s. 75-80, http://www.centerforresilient children.org [dostęp: 21.03.2015].

34 P.A. LeBuffe, V.B. Shapiro, J.A. Naglieri, The Devereux Student Strengths Assessment (DESSA), Kaplan Press, NC: Lewisville 2009.

35 C.L Jew, K.E. Green, J. Kroger, Development and validation of a measure of resiliency, Measurement and Evaluation in Counseling and Development, 1999, 32(3).

36 S. Prince-Embury, Resiliency Scales for Children \& Adolescents ${ }^{\mathrm{TM}}$ - A Profile of Personal Strengths (RSCA), http://www.pearsonclinical.com/psychology/products/100000655/resilien 
- Adolescent Resilience Questionnaire (ARQ) ${ }^{37}$.

Przegląd narzędzi opublikowany przez Basca ${ }^{38}$ może inspirować do poszukiwania interesujących narzędzi badawczych. Zawiera bowiem opis 26 narzędzi badawczych przeznaczonych do badania zasobów u dzieci i młodzieży, to jest na przykład kompetencje społeczne, poczucie własnej wartości, poczucie sprawstwa, w tym cztery dotyczą resiliency. Wśród omawianych narzędzi znalazły się, obok dwóch wymienianych $\mathrm{w}$ pozostałych przeglądach, wcześniej nie wymieniane:

- Healthy Kids Resilience Assesment (HKRA) ${ }^{39}$;

- Individual Protective Factors Index (IPFI) ${ }^{40}$.

Poniżej zostaną omówione wybrane narzędzia badawcze, to jest The Resilience Scale (RS) Wagnilda i Younga, ponieważ w przeglądzie Windle'a i wsp. oraz Ahern i wsp. narzędzie to uzyskało najwyższe noty dla narzędzi do pomiaru rezyliencji wśród dzieci i młodzieży. Z przeglądu Kordich Hall do prezentacji wybrano skale DECA i DESSA, jako że odnoszą się one do dzieci i bliżej nie były opisywane $\mathrm{w}$ polskiej literaturze przedmiotu oraz Resiliency Belief System Scale (RBS) Jew i wsp. z uwagi na zdawkowe informacje o niej w polskich źródłach. Natomiast na zakończenie zostaną przedstawione dwa wcześniej nie prezentowane narzędzia opisane przez Basca. Na uwagę zasługuje też, z powodu dużego zainteresowania $\mathrm{w}$ wielu krajach, skala Child and Youth Resilience Measure (CYRM).

\section{Charakterystyka wybranych narzędzi badawczych}

Podstawowa charakterystyka narzędzi obejmuje takie informacje, jak pełna i skrócona oryginalna nazwa narzędzia, zaś po niej w odsyłaczu nazwiska twórcy/ów narzędzia, tytuł i rok wydania pracy, w której znajduje się charakterystyka narzędzia. Ponadto, $\mathrm{w}$ tekście zamieszczono informacje o: teoretycznych założeniach leżących u podstaw konstrukcji narzędzia,

\footnotetext{
cy-scales-for-children-adolescents-a-profile-of-personal-strengths-rsca.html\#tab-resources, [dostęp: 21.09.2015].

37 D. Gartland i in., Centre for Adolescent Health, Royal Children's Hospital, Melbourne, Australia 2006, http:/ / www.ahda.org/downloads/ISSBD2006Gartland.pdf.

38 B. Basca. Literature review of youth development/asset tools.

${ }^{39}$ N.A. Constantine, B. Benard, M. Diaz, Measuring Protective Factors and Resilience Traits in Youth: The Healthy Kids Resilience Assessment, School and Community Health Research Group WestEd, Oakland, CA 1999, http://crahd.phi.org/papers/HKRA-99.pdf [dostęp 15.09.2015].

${ }^{40}$ J.F. Springer, J.L. Phillips, Individual Protective Factors Index (IPFI): A measure of adolescent resiliency, EMT Associates, Inc. Folsom, CA 1997, http://www.emt.org [dostęp: 25.05.2015].
} 
konstrukcji i właściwościach psychometrycznych narzędzia, docelowej grupie badawczej wraz $\mathrm{z}$ określeniem jej wieku, badanych zmiennych/ wymiarach.

\section{Resilience Scale (RS) ${ }^{41}$}

Skala powstała jako rezultat wywiadów przeprowadzonych z setkami ludzi, którzy pokonali napotkane przeciwności losu. Służy do pomiaru resiliency u młodzieży i dorosłych, za pomocą takich wymiarów, jak kompetencje osobiste i akceptacja siebie oraz swojego życia. Istnieją dwie wersje skali. Jedna składa się z 25 itemów, a druga - z 14 itemów. Respondenci odnoszą się do stwierdzeń za pomocą 7-punktowej skali szacunkowej. Oto przykładowe itemy: jestem przyjacielem samego siebie, jestem zdecydowany, wiara w siebie pomaga mi przezwyciężyć trudne czasy, moje życie ma sens, kiedy jest się w trudnej sytuacji można zwykle znaleźć rozwiązanie. Autorzy skali na podstawie kilku przeprowadzonych badań podali spójność wewnętrzną skali na poziomie alfa Cronbacha - od 0,76 do 0,91. Narzędzie jest upowszechniane na stronie internetowej http://www.resiliencescale.com, poprzez którą prowadzona jest też jego sprzedaż. G. Windle i wsp. zwracają uwagę, że skala umożliwia jedynie ocenę stopnia, w jakim resiliency jednostki wzmacnia jej indywidualną adaptację ${ }^{42}$. Ponadto, ma zastosowanie tylko do młodzieży starszej. Autorom narzędzia zarzuca się brak pełnych informacji na temat teoretycznych podstaw narzędzia i pewne nieścisłości $\mathrm{z}$ tym związane, widoczne $\mathrm{w}$ jego konstrukcji. Pomimo tego skala $\mathrm{w}$ dwóch przeglądach otrzymała najwyższe noty dla skal mierzących resiliency u młodzieży.

Skala RS znalazła zastosowanie w polskich badaniach HBSC (Health Behaviour in School-aged Children. WHO Collaborative Study ${ }^{43}$ w 2006 roku do pomiaru dodatkowych czynników wpływających na odporność młodzieży na zagrożenia, które nie zostały uwzględnione w międzynarodowym

${ }^{41}$ G.M. Wagnild, H.M. Young, Development and psychometric evaluation of the Resilience Scale, Journal of. Nursing Measurement, 1993, 1(2), s. 165-178.

${ }^{42}$ G. Windle. K.M. Bennett, J. Noyes, A methodological review of resilience measurement scales, s. 11.

43 Są to międzynarodowe badania ankietowe nad zachowaniami zdrowotnymi młodzieży szkolnej prowadzone cyklicznie od 1982 roku. Dostarczają one informacji na temat stanu zdrowia i stylu życia młodzieży pochodzącej z Europy i Ameryki Północnej. 
protokole badań HBSC ${ }^{44}$. Ostatecznie autorzy badań uwzględnili w swoim projekcie 4 pytania dotyczące: odczuwania dumy z własnych osiągnięć, znajdowania powodów do radości, wiary w siebie pozwalającej radzić sobie z trudnymi okresami w życiu, przekonania o wartości własnego życia. Skala otrzymała nazwę: „Postawa wobec siebie i świata"45. Poddano ją analizie psychometrycznej ${ }^{46}$. Ahern i wsp. w swoim przeglądzie narzędzi do pomiaru rezyliencji uznali RS za najbardziej odpowiedni instrument do badania tego zjawiska, ze względu na właściwości psychometryczne narzędzia i możliwość jego zastosowania w młodszych niż pierwotnie zakładano grupach wiekowych. Podobnej oceny dokonali Wagnild i wsp. ${ }^{47}$

\section{Devereux Early Childhood Assessment Program (DECA) ${ }^{48}$}

Narzędzie zostało opracowane dla potrzeb Programu DECA, nastawionego na promocję zdrowego rozwoju społeczno-emocjonalnego małych dzieci (2-5 r.ż.), oparte na wzmacnianiu czynników chroniących. DECA służy do identyfikacji zjawiska rezyliencji i czynników chroniących oraz rozpoznawania zachowań problemowych. Teoretyczną podstawą do konstrukcji narzędzia była koncepcja rezyliencji, która zdaniem autorów jest niezwykle obiecująca przy projektowaniu oddziaływań pomocowych związanych z samym programem. Na kwestionariusz DECA składa się 27-itemowa skala, służąca do identyfikacji czynników chroniących. W jej skład wchodzą 3 podskale szczegółowe (mierzą: inicjatywę, samokontrolę i przywiązanie) i jedna podskala do całościowego określenia indeksu czynników chroniących. Uzupełnienia obrazu społeczno-emocjonalnego rozwoju dziecka dostarcza zawarta $\mathrm{w}$ narzędziu skala do pomiaru zachowań problemowych, złożona z 10 itemów. Istnieje także wersja kliniczna DECA-C narzędzia 62-itemowa do identyfikacji problemów ze zdrowiem psychicznym dzieci. Kwestionariusze wypełniają rodzice bądź członkowie rodziny dziecka oraz

${ }^{44}$ H. Kołoło, J. Mazur, Zaangażowanie w konstruktywna działalność oraz wybrane zasoby osobiste jako czynniki chroniace w grupie posiadanych kompetencji, [w:] Czynniki chroniace młodzież 15-letnia, s. 19-45.

${ }^{45} \mathrm{~W}$ niektórych opracowaniach pojawia się pod nazwą "Optymizm życiowy”.

46 Precyzyjne informacje o polskich badaniach pilotażowych z zastosowaniem skali oraz o wynikach analizy psychometrycznej w znaleźć można w przywołanej powyżej pracy: H. Kołoło, J. Mazur, Zaangażowanie w konstruktywna dziatalność.

47 G.M. Wagnild, H.M. Young, Development and psychometric evaluation of the Resilience Scale, s. 165-178.

48 P.A. LeBuffe, V.B. Shapiro, J.A. Naglieri, The Devereux Student Strengths Assessment (DESSA). 
pracownicy wczesnej opieki nad dzieckiem i edukacji, w myśl zasady koniecznego partnerstwa pomiędzy rodzicami a instytucjonalnymi opiekunami na rzecz wzmacniania rozwoju społeczno-emocjonalnego dzieci. Zebrane za pomocą narzędzia wyniki wykorzystuje się do opracowania indywidualnego profilu dziecka (jego mocnych i słabych stron), w celu identyfikacji dzieci o niewystarczających zasobach i zaprojektowania strategii oddziaływań w instytucji i rodzinie. Poza tym, skala umożliwia opracowanie grupowego profilu wszystkich dzieci, co również ma służyć projektowaniu oddziaływań na rzecz wzmacniania zasobów dzieci. Skala do pomiaru zachowań problemowych przydatna jest do identyfikowania dzieci wymagających interwencji $z$ uwagi na ujawnione problemy w sferze emocjonalnobehawioralnej ${ }^{49}$. Autorzy narzędzia przeprowadzili obszerne badania, których wyniki wskazują na wysokie parametry psychometryczne ${ }^{50}$.

\section{Devereux Student Strengths Assessment (DESSA) ${ }^{51}$}

Za pomocą tego narzędzia można dokonać oceny poziomu kompetencji społeczno-emocjonalnych i umiejętności szkolnych u dzieci szkolnych (5-14 r.ż.), które uważa się za najistotniejsze czynniki chroniące dla ich prawidłowego rozwoju i na tej podstawie wnioskuje o rezyliencji dzieci. Narzędzie składa się z 72 itemów rozmieszczonych na 8 podskalach odnoszących się do kluczowych kompetencji społecznych. Badane wymiary to: samoświadomość, społeczna świadomość, kierowanie sobą, celowe kierowanie własnym zachowaniem, umiejętności nawiązywania relacji z innymi, osobista odpowiedzialność, podejmowanie decyzji, optymistyczne myślenie. Kwestionariusz adresowany jest do rodziców, opiekunów, nauczycieli i wychowawców pozaszkolnych. Na podstawie wyników oceniany jest poziom poszczególnych wymiarów kompetencji u każdego ucznia z klasy. Na podstawie danych zebranych od rodziców i nauczycieli przygotowywany jest tzw. indywidualny profil ucznia, potem klasy celem opracowania wskazówek odnoszących się do praktyki interwencyjnej dla każdego ucznia od-

49 Dane pochodzą z http://www.centerforresilientchildren.org/preschool/assessmentsresources/the-devereux-early-childhood-assessment-preschool-program-second-edition/ [dostęp: 20.03.2015].

50 Obszerne raporty z badań znajdują się na stronie organizacji Deveraux Center for Resilient Children http://www.centerforresilientchildren.org/home/about-us/summary-techni cal-information-assessment-tools/.

${ }^{51}$ P.A. LeBuffe, V.B. Shapiro, J.A. Naglieri, The Devereux Student Strengths Assessment (DE$S S A)$. 
dzielnie i dla całej klasy. Standaryzację narzędzia przeprowadzono na 2,5-tysięcznej populacji w odniesieniu do dzieci pochodzących ze wszystkich 50 stanów Ameryki Północnej. Rzetelność każdej skali okazała się wysoka (alfa Cronbacha równa i powyżej 0,82). Popularyzacja i dystrybucja narzędzia badawczego DESSA odbywa się za pośrednictwem strony Centrum DCRC http://www.devereux.org ${ }^{52}$.

\section{Resiliency Belief System Scale (RBS) ${ }^{53}$}

Narzędzie opiera się na poznawczej interpretacji koncepcji rezyliencji dokonanej przez Patricię J. Mrazek i Davida A. Mrazek w 1987 roku$^{54}$ (ang. theory of resilience), zgodnie z którą reakcje na stres mogą być uzależnione od oceny sytuacji i zdolności człowieka do przetwarzania doświadczenia w system przekonań. Badacze zidentyfikowali 12 właściwości wykorzystywanych przez rezylientne osoby do radzenia sobie ze stresem. Są to (1) szybkie reagowanie na zagrożenia, (2) przedwczesna dojrzałość, (3) zdolność do dystansowania się od intensywnych uczuć, (4) poszukiwanie informacji np. o zagrożeniach, (5) tworzenie i wykorzystanie relacji do przetrwania, (6) pozytywne przewidywanie przyszłości, (7) branie odpowiedzialności za podejmowane decyzje pomimo ryzyka, (8) przekonanie o byciu kochanym, (9) idealizacja kompetencji agresora, (10) poznawcza restrukturyzacja bolesnych wydarzeń, (11) altruizm, (12) optymizm i nadzieja55. Te 12 właściwości stało się podstawą do konstrukcji RS. Autorzy skali przyjęli założenie, że istnieją określone cechy psychiczne, które związane są z rezyliencją i znajdują odzwierciedlenie $w$ umiejętnościach oraz zdolnościach, których ludzie używają w sytuacjach stresowych. Resiliency wynika z układu specyficznych przekonań współdziałających ze stresorami środowiskowymi, co

52 Dane pochodzą z http://www.centerforresilientchildren.org/school-age/assessmentsresources/the-devereux-student-strengths-assessment-dessa-kit/ [dostęp:20.03.2015] i wymienionej wyżej pracy P.A. LeBuffe, V.B. Shapiro, J. A. Naglieri. Wszystkie raporty z badań nad oceną psychometryczną narzędzia znajdują się na stronie organizacji Deveraux Center for Resilient Children http://www.centerforresilientchildren.org/home/about-us/summarytechnical-information-assessment-tools/.

53 Część informacji zaczerpnięto z przeglądu autorstwa M.R. O'Neal, Measuring Resilience, http://eric.ed.gov/?id=ED436574 [dostęp: 18.02.2015]; C.L. Jew, K.E. Green, J. Kroger, Development and validation of a measure of resiliency.

54 Mowa o artykule: P.J. Mrazek, D.A. Mrazek, Resilience in child maltreatment victims: A conceptual exploration, Child Abuse and Neglect, 1987, 11, s. 357-365.

55 M.R. O'Neal, Measuring Resilience, http://eric.ed.gov/?id=ED436574 [dostęp: 18.02.2015]. 
pozwala określić zdolności danej osoby do radzenia sobie ze stresem. Te przekonania to postrzeganie siebie, swoich zdolności, swoich relacji i zalet świata. Rozwój tych przekonań związany jest z osobowością, środowiskiem i stadium rozwoju jednostki.

Skala składa się z trzech podskal mierzących: zorientowanie na przyszłość (19 itemów), aktywne nabywanie umiejętności (10 itemów) i skłonność do podejmowania ryzyka (6 itemów). Każda z trzech podskal ma zadowalającą spójność wewnętrzną na poziomie 0,91 dla pierwszej, 0,79 dla drugiej i 0,68 dla skali związanej z podejmowaniem ryzyka. Autorzy odnotowali istotne korelacje skal ze zmienną: radzenie sobie ze stresem. Ponadto, RS skutecznie odróżniała młodzież przebywającą w instytucjach i wychowującą się $\mathrm{w}$ środowisku rodzinnym, jak również tę samodzielnie zgłaszającą zagrożenia $\mathrm{w}$ porównaniu z niezagrożoną.

\section{Child and Youth Resilience Measure (CYRM-28) ${ }^{56}$}

To narzędzie badawcze wydaje się niezwykle obiecujące, ponieważ nad jego kulturową i kontekstową trafnością pracował międzynarodowy zespół badaczy z 11 krajów. Zespół wykorzystał metodę mieszaną ilościowojakościową, ułatwiającą zrozumienie projektowania zarówno wspólnych, jak i unikalnych aspektów rezyliencji w różnych kulturach. Badania przeprowadzono w 11 krajach na 1500-osobowej populacji młodzieży z grup ryzyka, która eksponowana była co najmniej na 3 czynniki ryzyka (np. narażenie na przemoc, wychowywanie się $\mathrm{w}$ instytucji opieki, problemy ze zdrowiem psychicznym, społecznym, bezdomność, ubóstwo, czy narażenie na zawirowania polityczne i wojny). U podstaw koncepcji badawczej znalazło się założenie, że rezyliencja jest konstruktem wielowymiarowym, którego definicja będzie zależeć od kontekstu kulturowego. Wyniki badań zespołu Ungara, zebrane za pomocą 89 wywiadów indywidualnych i historii życia od dzieci w 14 różnych miejscach na świecie, oraz obserwacje pięciu grup młodzieży, a także 12 wywiadów z dorosłymi w różnych środowiskach ujawniły, że nawet $w$ obliczu podobnych przeciwności sposoby radzenia sobie są bardzo zróżnicowane. CYRM adresowane jest do młodzieży z grup ryzyka od 13. roku życia wzwyż. Składa się 28 itemów rozłożonych na 4 skalach dotyczących: czynników indywidualnych (tj. umiejętności osobiste i spo-

${ }^{56}$ M. Ungar (red.), Handbook for working with children and youth: Pathways to resilience across cultures and contexts, Sage Publications, Thousand Oaks, CA 2005; L. Liebenberg, M. Ungar (red.), Researching resilience, Toronto 2009. 
łeczne); czynników odnoszących się do relacji (tj. wsparcie rówieśnicze; zapewnianie opieki fizycznej i psychicznej); czynników kontekstualnych przyczyniających się posiadania poczucia przynależności; komponentów związanych z duchowością, kulturą i edukacją. Badania potwierdziły rzetelność narzędzia i jego przydatność do badań nad rezyliencją wśród młodzieży z różnych środowisk kulturowych.

\section{The Healthy Kids Resilience Assesment (HKRA) ${ }^{57}$}

Skala ta jest elementem większego modułu diagnostycznego o nazwie California Healthy Kids Survey. Narzędzie opracowali: Norman A. Constantine, Bonnie Benard i Marycruz Diaz (School and Community Health Research Group WestEd w Oakland). Teoretyczną podstawę narzędzia stanowi koncepcja rezyliencji. Autorzy przyjęli założenie, że prawidłowy przebieg procesu rozwoju psychospołecznego uzależniony jest od działania zarówno zewnętrznych, jak i wewnętrznych czynników chroniących, które stanowią wewnętrzną siłę napędową $\mathrm{w}$ radzeniu sobie przez jednostkę z przeciwnościami losu. Przy czym, właściwości te traktowane są jako rezultaty, a nie przyczyny procesu rozwojowego.

Początkowo narzędzie zaprojektowano do pomiaru 11 czynników chroniących i 11 cech resiliency rozmieszczonych na sześciu wymiarach. Badania walidacyjne przeprowadzono na ponad 50-tysięcznej próbie badawczej dzieci uczących się na poziomach nauczania od 7-11-tego, z 479 szkół rozmieszczonych w 164 dystryktach stanu Kalifornia. Analizy trafności prowadzono na kilku etapach pracy nad narzędziem, które przez lata podlegało kolejnym modyfikacjom. Obecnie dostępna jest wersja 4.0. Narzędzie składa się z 6 skal do oceny czynników chroniących, które tkwią w rodzinie, szkole, społeczności lokalnej i samej jednostce. Aktualnie zawiera 52 itemy.

\section{Individual Protective Factors Index (IPFI) 58}

IPFI jest 71-elementową skalą do pomiaru resiliency u adolescentów i młodzieży definiowanej za pomocą dziesięciu różnych postaw zawartych w trzech wymiarach: nawiązywania więzi społecznych, osobistych kompe-

${ }^{57}$ https://www.wested.org/resources/healthy-kids-resilience-module-hkrm/ [dostęp: 20.09.2015].

${ }^{58}$ J.F. Springer, J.L. Phillips, Individual Protective Factors Index (IPFI). 
tencji i kompetencji społecznych. Pomiar więzi społecznych obejmuje szkołę, rodzinę i postawy prospołeczne, natomiast w zakresie kompetencji osobistych takie zmienne, jak postrzeganie siebie, samokontrola, poczucie skuteczności i pozytywne nastawienie. Badanie kompetencji społecznych sprowadza się zaś do pomiaru postawy asertywnej, pewności siebie i umiejętności współpracy. Autorzy deklarują, że pomiar konstruktów zawiera te wymiary, jakie w literaturze dotyczącej zdrowego rozwoju osobistego i społecznego młodzieży z grup ryzyka wymieniane są najczęściej. Autorzy wskazują IPFI jako narzędzie użyteczne do ewaluacji programów profilaktycznych adresowanych do dzieci i młodzieży od 10. do 16. roku życia. Narzędzie weryfikowano $\mathrm{w}$ toku badań pilotażowych $\mathrm{z}$ udziałem ponad 642-osobowej próby z grupą kontrolną, liczącą przeszło 2416 młodych osób. Narzędzie posiada wysokie parametry psychometryczne - alfa Cronbacha dla narzędzia wynosi 0,9359 .

\section{Podsumowanie}

Przeprowadzona przez autorkę niniejszego artykułu ogólna analiza polskiej i zagranicznej literatury przedmiotu dowodzi, że brakuje rodzimych, jak również zagranicznych narzędzi badawczych do pomiaru zjawiska rezyliencji, zwłaszcza rozumianego jako proces. Deficyt ten dotyczy szczególnie narzędzi do badania zjawiska wśród dzieci i młodzieży. Większość narzędzi badawczych odnosi się do pomiaru rezyliencji rozumianej w kategoriach właściwości jednostki (resiliency) i niewiele z nich posiada zadowalające właściwości psychometryczne. Przykładem są następujące narzędzia badawcze zaprezentowane w tym artykule: Resilience Scale (RS), Devereux Student Strengths Assessment (DESSA/DESSA - mini), Resiliency Belif System Scale (RBS), The Healthy Kids Resilience Assessment (HKRA), Individual Protective Factors Index (IPFI). Wszystkie powyżej wymienione koncentrują się głównie na pomiarze wewnętrznych zasobów dzieci i młodzieży. Chociaż HKRA służy między innymi do pomiaru zewnętrznych czynników chroniących, to jednak nie uwzględnia pomiaru czynników ryzyka, co jest warunkiem wnioskowania o występowaniu rezyliencji rozumianej jako proces. Dlatego, nazwy niektórych narzędzi należałoby uznać za błędne i mylące dla badaczy poszukujących skal do pomiaru rezyliencji rozumianej jako proces. Obiecujące jest za to narzędzie Child and Youth Resilience Measure

59 B. Basca, Literature review of youth development/asset tools, The EMT Group, Inc. 2002, http://www.emt.org/userfiles/YouthLit_Final.pdf, [dostęp: 15.06.2015]. 
(CYRM-28), adresowane do grup ryzyka, uwzględniające pomiar co najmniej 3 czynników ryzyka oraz zewnętrzne i wewnętrzne czynniki chroniące. Stąd, narzędzie to należy uznać za najbardziej adekwatne do pomiaru rezyliencji rozumianej jako proces.

W literaturze zagranicznej istnieje niewiele przeglądów narzędzi badawczych, które spełniałyby kryteria poprawności metodologicznej, co mogłoby ułatwić ich wybór do adaptacji kulturowej, a także stanowić inspiracje do konstrukcji narzędzi rodzimych.

Deficyt narzędzi badawczych do pomiaru zjawiska rezyliencji definiowanego jako proces wydaje się zrozumiały, ponieważ badanie procesu zawsze jest zadaniem skomplikowanym, tym bardziej że rezyliencji nie da się mierzyć w sposób bezpośredni, a jedynie można o niej wnioskować na podstawie interakcji pomiędzy czynnikami ryzyka i czynnikami chroniącymi uruchamiającymi określone mechanizmy ${ }^{60}$. Autorzy narzędzi najczęściej uwzględniają takie zmienne, jak behawioralne kompetencje lub stopień w jakim młoda osoba spełnia oczekiwania społeczne, czy też pełni role społeczne (rola ucznia czy kolegi) oraz przestrzega norm społecznych. Rzadziej projektuje się narzędzia, w których same dzieci mają szansę wypowiadania się na swój temat, co najczęściej jest udziałem dorosłych.

Deficyt przeglądów narzędzi badawczych w polskich pracach naukowych wynika prawdopodobnie $\mathrm{z}$ tempa, w jakim rozwijają się nurty badań nad rezyliencją. Można przypuszczać, że wraz ze wzrostem zainteresowania badaniami nad rezyliencją dzieci i młodzieży pojawią się tego typu przeglądy.

\section{BIBLIOGRAFIA}

Ahern N.R., Kiehl E.M., Sole M., Byers J., A Review of Instruments Measuring Resilience, Issues in Comprehensive Pediatric Nursing, 2006, 29(2).

${ }^{60}$ K. Okulicz-Kozaryn, K. Bobrowski, Czynniki ryzyka, czynniki chroniace i indeksy tych czynników w badaniach nad zachowaniami problemowymi nastolatków, Alkoholizm i Narkomania, 2008, 21(2), s. 173-199.

Potwierdzeniem złożoności takiego procesu są badania nad zachowaniami ryzykownymi młodzieży i modelami resilience autorstwa Krzysztofa Ostaszewskiego (2014), których jednym z celów było wyjaśnianie mechanizmów resilience. Autor poddał weryfikacji dwa modele zależności pomiędzy indeksami psychospołecznego ryzyka/ochrony a syndromem zachowań ryzykownych oraz modele szczegółowe zakładające działanie wybranych psychospołecznych czynników ryzyka/ochrony na nasilenie syndromu zachowań ryzykownych. Do osiągnięcia tego celu wykorzystał wysoko zaawansowane metody statystyczne, co wymaga wysokich kompetencji naukowych. Dlatego też sądzę, że powodem niepodejmowania konstrukcji narzędzi do pomiaru rezyliencji traktowanej jako proces są trudności natury metodologicznej. 
Basca B., Literature review of youth development/asset tools, The EMT Group, Inc. 2002, http:/ / www.emt.org/userfiles/YouthLit_Final.pdf, [dostęp: 15.06.2015].

Block J., Kremen A.M., IQ and ego-resiliency: Conceptual and empirical connections and separateness, Journal of Personality and Social Psychology, 1996, 70.

Borucka A., Koncepcja resilience. Podstawowe zatożenia i nurty badań, [w:] Resilience. Teoria badania - praktyka, red. W. Junik, Wydawnictwo Edukacyjne Parpamedia, Warszawa 2011.

Borucka A., Ostaszewski K., Koncepcja resilience. Kluczowe pojęcia i wybrane zagadnienia, Medycyna Wieku Rozwojowego, 2008, XII, 2, I.

Brooks J.E., Strengthening resilience in children and youths: Maximizing opportunities through the schools, Children and Schools, 2006, 28(2).

Constantine N.A., Benard B., Diaz M., Measuring Protective Factors and Resilience Traits in Youth: The Healthy Kids Resilience Assessment, School and Community Health Research Group WestEd, Oakland, CA 1999, http://crahd.phi.org/papers/HKRA-99.pdf [dostęp 15.09.2015].

Fergus S., Zimmerman M.A., Adolescent Resilience: A Framework for Understanding Healthy Development in the Face of Risk, Annual Reviews Public Health, 2005, 26.

Gartland D., Bond L., Olsson C., Buzwell S., Sawyer S., Centre for Adolescent Health, Royal Children's Hospital, Melbourne, Australia 2006, http://www.ahda.org/ downloads/ISSBD2006Gartland.pdf.

Grzegorzewska I., Odporność psychiczna dzieci alkoholików, Wydawnictwo Naukowe Scholar, Warszawa 2013.

http://www.centerforresilientchildren.org/preschool/assessments-resources/the-dever eux-early-childhood-assessment-preschool-program-second-edition/ [dostęp: 20.03. 2015].

https://www.wested.org/resources/healthy-kids-resilience-module-hkrm/ [dostęp: 20.09.2015].

Jew C.L, Green K.E., Kroger J., Development and validation of a measure of resiliency, Measurement and Evaluation in Counseling and Development, 1999, 32(3).

Junik W., Zjawisko rezyliencji - wybrane problemy metodologiczne, [w:] Resilience. Teoria badania - praktyka, red. W. Junik, Wydawnictwo Edukacyjne Parpamedia, Warszawa 2011.

Kaczmarek Ł., Sęk H., Ziarko M., Sprężystość psychiczna i zmienne pośredniczace w jej wptywie na zdrowie, Przegląd Psychologiczny, 2011, 54, 1.

Kołoło H., Mazur J., Zaangażowanie w konstruktywna działalność oraz wybrane zasoby osobiste jako czynniki chroniace w grupie posiadanych kompetencji, [w:] Czynniki chroniace młodzież 15-letnia przed podejmowaniem zachowań ryzykownych, Raport z badań HBSC 2006, red. J. Mazur, I. Tabak, A. Małkowska-Szkutnik, K. Ostaszewski, H. Kołoło, A. Dzielska, A. Kowalewska, Instytut Matki i Dziecka, Warszawa 2008.

Kordich Hall D., Compendium of Selected Resilience and Related Measures for Children and Youth. APPENDIX E: Annotated Compendium of Resilience Measures Reaching IN Reaching OUT, The Child \& Family Partner, Toronto 2010, http://www.reachin ginreachingout.com/documents/APPENDIX\%20E\%20-\%20Annotated \%20Com pendium\%20of\%20Resilience\%20Measures.pdf [dostęp: 18.02.2015].

LeBuffe P.A., Naglieri J.A., The Devereux Early Childhood Assessment (DECA): A Measure of Within-Child Protective Factors in Preschool Children, NHSA Dialog: A Research-toPractice Journal for the Early Childhood Field, 1999, 3, 1, s. 75-80, http://www. centerforresilientchildren.org [dostęp: 21.03.2015]. 
LeBuffe P.A., Shapiro V.B., Naglieri J.A., The Devereux Student Strengths Assessment (DESSA), Kaplan Press, NC: Lewisville 2009.

Liebenberg L., Ungar M. (red.), Researching resilience, University of Toronto Press, Toronto 2009.

Mazur J., Tabak I., Koncepcja resilience od teorii do badań empirycznych, [w:] Czynniki chroniace młodzież 15-letnia przed podejmowaniem zachowań ryzykownych, Raport $\mathrm{z}$ badań HBSC 2006, red. J. Mazur, I. Tabak, A. Małkowska-Szkutnik, K. Ostaszewski, H. Kołoło, A. Dzielska, A. Kowalewska, Instytut Matki i Dziecka, Warszawa 2008.

Mrazek P.J., Mrazek D., Resilience in child maltreatment victims: A conceptual exploration, Child Abuse and Neglect, 1987, 11.

Nadolska K., Sęk H., Społeczny kontekst odkrywania zasobów odpornościowych, czyli czym jest resilience i jak ono funkcjonuje, [w:] Bliżej serca, red. Ł. Kaczmarek, A. Słysz, Wydawnictwo Naukowe UAM, Poznań 2007.

Ogińska-Bulik N., Juczyński Z., Osobowość. Stres a zdrowie, Wydawnictwo Difin, Warszawa 2008.

Ogińska-Bulik N., Juczyński Z., Skala Pomiaru Prężności (SPP-25), Nowiny Psychologiczne, 2008, 3 .

Ogińska-Bulik N., Juczyński Z., Prężność u dzieci i młodzieży: charakterystyka i pomiar Polska skala SPP-18, Polskie Forum Psychologiczne, 2011, 16, 1.

Okulicz-Kozaryn K., Bobrowski K., Czynniki ryzyka, czynniki chroniace i indeksy tych czynników w badaniach nad zachowaniami problemowymi nastolatków, Alkoholizm i Narkomania, 2008, 21(2).

O'Neal M.R., Measuring Resilience, http:/ / eric.ed.gov/?id=ED436574 [dostęp: 18.02.2015].

Opora R., Ewolucja niedostosowania spotecznego jako rezultat zmian w zakresie odporności psychicznej i znieksztatceń poznawczych, Wydawnictwo Uniwersytetu Gdańskiego, Gdańsk 2009.

Ostaszewski K., Druga strona ryzyka, Remedium, 2005, 2(144).

Ostaszewski K., Czynniki ryzyka i czynniki chroniące w zachowaniach ryzykownych dzieci i młodzieży, [w:] Czynniki chroniące młodzież 15-letnia przed podejmowaniem zachowan ryzykownych, Raport z badań HBSC 2006, red. J. Mazur, I. Tabak, A. MałkowskaSzkutnik, K. Ostaszewski, H. Kołoło, A. Dzielska, A. Kowalewska, Instytut Matki i Dziecka, Warszawa 2008.

Ostaszewski K., Badania warszawskich gimnazjalistów. Koncepcja i metoda, [w:] Promocja zdrowia psychicznego, badania i działania w Polsce. Część druga, red. K. OkuliczKozaryn, K. Ostaszewski, Instytut Psychiatrii i Neurologii, Warszawa 2010.

Ostaszewski K., Zachowania ryzykowne młodzieży w perspektywie mechanizmów resilience, Instytut Psychiatrii i Neurologii, Warszawa 2014.

Ostaszewski K., Rustecka-Krawczyk A., Wójcik M., Czynniki chroniące i czynniki ryzyka związane z zachowaniami problemowymi warszawskich gimnazjalistów. Raport z realizacji I etapu badań: „Rola czynników ryzyka i czynników chroniących w rozwoju zachowań problemowych u młodzieży szkolnej. Badania warszawskich gimnazjalistów”, Warszawa 2008.

Prince-Embury S., Resiliency Scales for Children \& Adolescents ${ }^{\mathrm{TM}}$ - A Profile of Personal Strengths (RSCA), http://www.pearsonclinical.com/psychology/products/1000 00655/resiliency-scales-for-children-adolescents-a-profile-of-personal-strengthsrsca.html\#tab-resources, [dostęp: 21.09.2015].

Risk to Resilience: Promoting School-Health Partnerships for Children, red. J.W. Richardson, International Journal of Educational Reform, Winter 2008, 17, 1. 
Sęk H., Kaczmarek Ł., Ziarko M., Pietrzykowska E., Lewicka J., Sprężystość psychiczna a dobrostan w chorobie przewlektej - mediujaca rola podmiotowego umocnienia i radzenia sobie, Polskie Forum Psychologiczne, 2012, 17.

Springer J.F., Phillips J.L., Individual Protective Factors Index (IPFI): A measure of adolescent resiliency. EMT Associates, Inc. Folsom, CA 1997, http://www.emt.org [dostęp: 25.05.2015].

Szwajca K., Sprężystość (resilience) i odpowiedzi na doświadczenia urazowe - fascynujący i trudny obszar badań, Psychiatria Polska, 2014, 48(3).

Tugde M.M, Fredrickson B.L., Resilient Individuals Use Positive Emotions to Bounce Back From Negative Emotional Experiences, Journal of Personality and Social Psychology, 2004, 86, 2.

Uchnast Z., Prężność osobowa: Empiryczna typologia i metoda pomiaru, Roczniki Filozoficzne, 1997, 4.

Ungar M. (red.), Handbook for working with children and youth: Pathways to resilience across cultures and contexts, Sage Publications, Thousand Oaks, CA 2005.

Valdenbilt-Adriance E., Shaw D.S., Conceptualizing and Re-Evaluating Resilience Across Levels of Risk, Time, and Domains of Competence, Clinical Child and Family Psychology Review, 2008.

Vitaro F., Carbonneau R., Assaad J.M., Les enfants de parents affectés d'une dépendence. Problemes et resilience, Press de l'Université du Québec, Québec 2006.

Wagnild G.M., Young H.M., Development and psychometric evaluation of the Resilience Scale, Journal of Nursing Measurement, 1993, 1(2).

Werner E.E., Children of the Garden Island, Scientific American, 1989, 260, 4.

Windle G., Bennett K.M., Noyes J., A methodological review of resilience measurement scales, Health and Quality of Life, 2011, 9.

Wolin S.J., Wolin S., The Resilient Self: How Survivors of Troubled Families Rise Above Adversity, Villard Books, New York 1993. 
